\title{
PROBLEMS OF SOLID WASTE MANAGEMENT FOR RECREATION ZONES OF ST PETERSBURG
}

\author{
Vladimir Zakrzhevsky \\ Andrey Konga
}

St Petersburg State University for Engineering and Economics, Russia

\begin{abstract}
More than 1.5 million city dwellers spend every summer in their garden houses in the sites around St Petersburg. Really it is a land of the Leningrad region. Total amount of solid waste from them is about 72.1 thousand ton per year. It is about $20 \%$ of total amount of waste from permanent habitants of these places. Besides 724.6 ton of waste per year is from short-term recreants who visit forests, lakes, rivers and other places for rest. The morphological structure of solid waste from the recreants essentially differs from structure of city waste: shares of metals and plastics are much more.

The most problem is that there is no a legal solid waste management system for recreants. One of the reasons is that recreants use territories outside places of living for permanent inhabitants. As a result numerous landfills have been appeared during last years. Dangerous contamination of surrounded soil and water is obvious. No special control from local authorities is existed. There is an urgent task to develop local legislation for recreant solid waste management. Unfortunately the Leningrad region has rather aged solid waste management. Practically only landfilling is used for solid waste. In the case of using only landfilling for recreant waste it is needed at least 47 ha of lands for new landfills.

The most reasonable alternative is a joint solid waste management for both permanent habitants and recreants. It will allow reducing cost of the whole system. In this case it will be easier to attract investment for introducing the appropriate system basing on modern technologies. Experience of Finland when neighboring municipalities combine their resources for solving this problem is the best way also for St Petersburg. In this case different methods of waste processing can be used: compost digesting, incineration, recycling and landfilling for the rest waste.
\end{abstract}

\section{KEYWORDS}

Long-term and short-term recreants; Gardening population; Recreation waste load; Morphology of solid waste; Legislation base; Landfilling

\section{INTRODUCTION}

Inhabitants of Saint Petersburg anyhow use territory of the Leningrad region and thus give negative impact on it. It concerns first citizens who have their garden houses in the region and also numerous short-term recreants, for example tourists who visit the Leningrad region 
mostly on weekends. We need to take into account many landfills, which are used for solid waste from St Petersburg.

\section{ESTIMATION OF RECREANT'S LOAD}

According to a rough estimate the number of inhabitants of St Petersburg, which have gardening sites in the Leningrad region reaches 1.5 million persons that is almost equalled to population of the Leningrad region (Figure 1). Rough estimation of the volume of waste from the gardening population is presented in Table 1 .

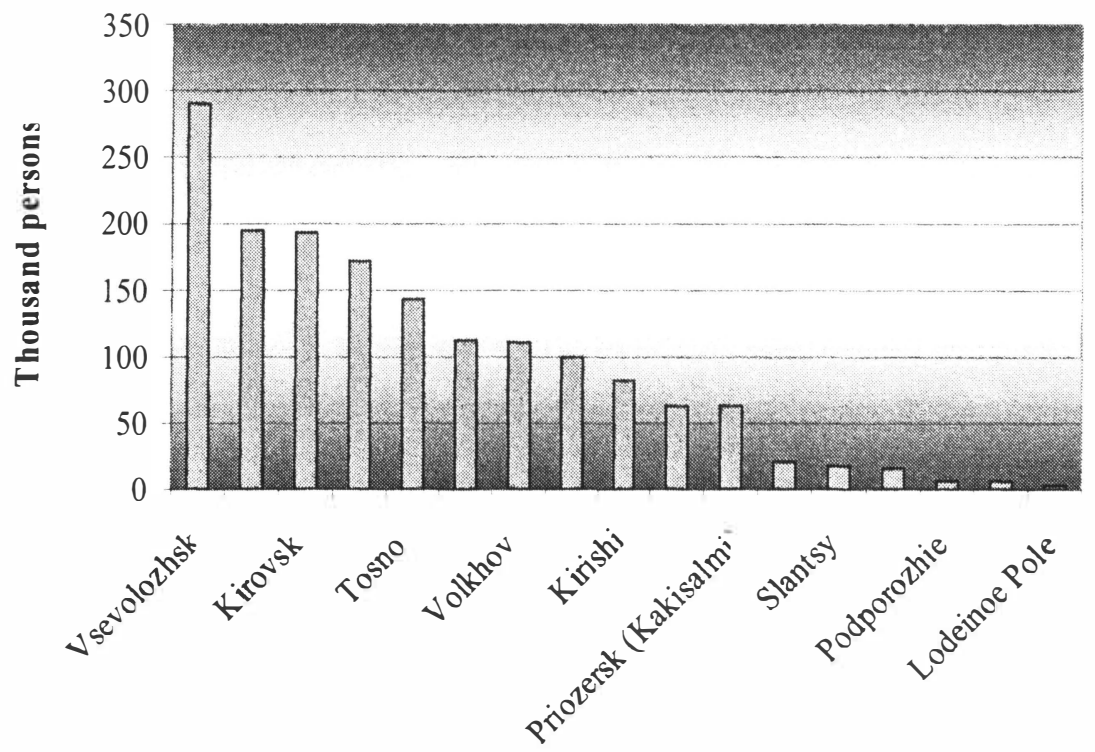

Figure 1. Number of the gardening population of the Leningrad region.

Scope of formation of solid waste for the given category of the population is based on use of "a factor of stay" equal to 0.43 , showing stay of the population in gardening sites from May till October.

It gives $365^{*} 0.43=157$ days that is about five months.

Thus amount of solid waste is $0.4 \mathrm{~m}^{3}(80 \mathrm{~kg})$ per capita that is $29,5 \%$ of annual amount for one citizen of St Petersburg.

Simultaneously amount of solid waste from short-term recreants also increases, but total amount from these recreants are less than one thousand ton that is $0.2-0.3 \%$ from total amount of waste produced in the Leningrad region. However because of localization of this waste in the most attractive places of landscape and because of their specific structure (wrapping and newsprint, cans from soft drinks, food residues) presence of these waste products always appreciably. 
Table 1. Rough estimation of the volume of waste from the gardening population.

\begin{tabular}{lcc}
\hline \multicolumn{1}{c}{ District } & $\begin{array}{c}\text { Number of the } \\
\text { gardening population, } \\
\text { Thousand persons }\end{array}$ & $\begin{array}{c}\text { Volume of solid waste, } \\
\text { Thousand ton }\end{array}$ \\
\hline Vsevolozhsk & 290.7 & 12.9 \\
\hline Vyborg & 195.7 & 8.7 \\
\hline Kirovsk & 194 & 8.5 \\
\hline Gatchina & 171.9 & 7.7 \\
\hline Tosno & 142.8 & 6.3 \\
\hline Luga & 113.1 & 5.5 \\
\hline Volkhov & 111.4 & 4.9 \\
\hline Lomonosov & 99.9 & 4.4 \\
\hline Kirishi & 81.8 & 3.6 \\
\hline Kingisepp & 62.4 & 2.7 \\
\hline Priozersk (Käkisalmi) & 62.1 & 2.8 \\
\hline Tikhvin & 21.1 & 0.9 \\
\hline Slantsy & 17.3 & 0.8 \\
\hline Boksigotogorsk & 15.4 & 0.7 \\
\hline Podporozhie & 6.4 & 0.4 \\
\hline Volosovo & 5.9 & 0.3 \\
\hline Lodeinoe Pole & 3.2 & 0.1 \\
\hline Total & 1595.1 & 71.2 \\
\hline
\end{tabular}

A morphological structure of solid waste for Saint Petersburg is submitted in Figure 2.

The morphological structure of solid waste made by gardeners essentially differs from structure of city waste. This structure is shown in Figure 3.

Such parameters are explained by features of a life for the given category of the population. Owners of summer residences and garden sites pawn some kinds of solid waste in compost heaps for producing fertilizers, but paper, cardboard, and also wood are mostly burnt.

On the other hand, the weight of waste of packing (metal cans from canned food and paints, empty capacities from plastics and composite materials) is higher in gardening households.

There are also some kinds of wastes not peculiar to citizens (used polyethylene from greenhouses, waste from roofing material, glass wool and other insulated materials, oven soot, etc.). The main part of household waste from this category of the population is formed in the Leningrad region within the warmest seven months of year - from April till October, and the maximum of their formation is in July and August 
Otber (stones, ceramics, bones, etc.)

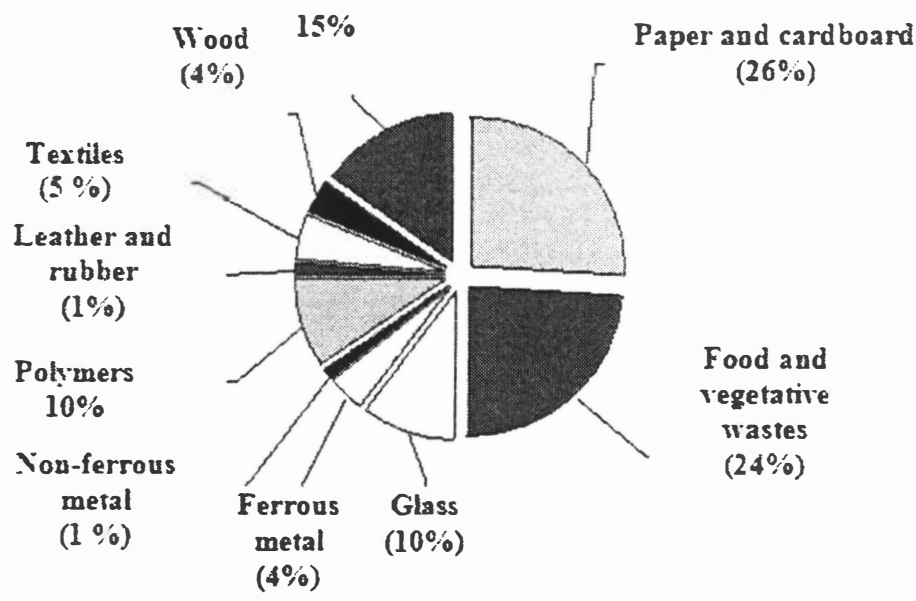

Figure 2. Morphological structure of solid waste in St Petersburg.

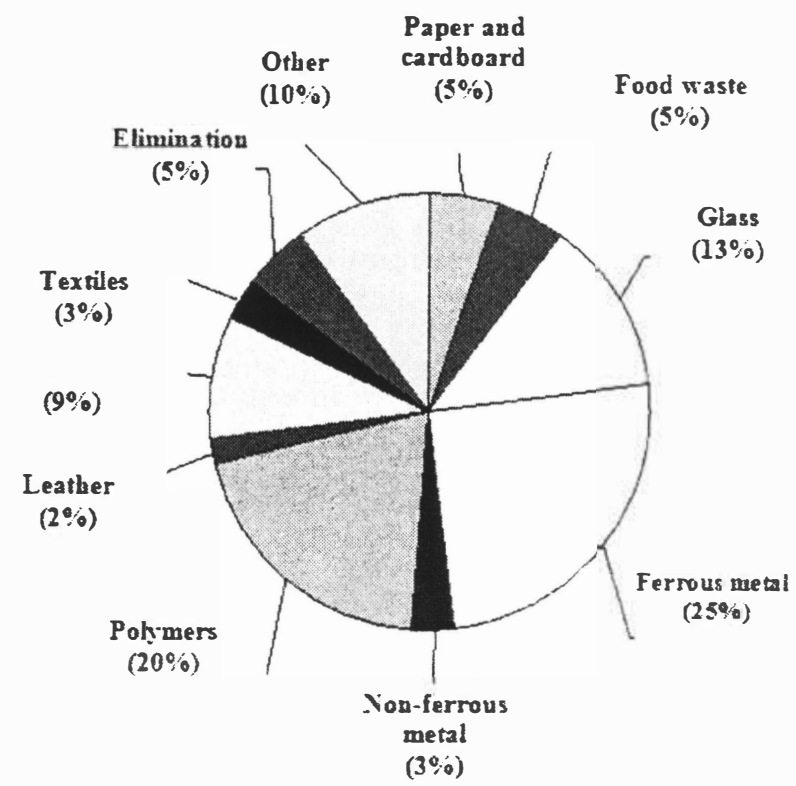

Figure 3. Morphological structure of waste from long-term recreants. 


\section{COMMON PROBLEMS FOR THE CITY AND THE REGION}

The analysis of the situation in the sphere of SWM in the city and the region has allowed

- There is no common system in the area for the waste account and control over its transfer and neutralization.

- Only $27 \%$ of waste from St Petersburg and less than $8 \%$ from the Leningrad region are processed at waste processing plants, other wastes are placed at the authorized and non-authorized dumps, the majority from which does not meet normative requirements. Waste from gardening sites are almost totally at numerous illegal dumps.

- Both in the city and in the region selective collecting and processing practically is not organized for household waste representing danger to the environment (used chemical batteries, products from polyvinyl chloride, things containing mercury, etc.).

- The system of collecting and processing of some kinds of large-sized wastes which formation shows the tendency to the fast growth, for example, such as the used tires, refrigerators, TVs, old cars is not organized.

- The amount of solid waste coming from St Petersburg to the Leningrad region and placing there at badly equipped dumps annually grows because of imperfections of a realizing tariff policy and the current legislative and normative base.

- The scheme of collecting of waste and the hardware in the sphere of SWM does not meet real needs that result a low part of waste recycling.

- There is no precisely organized a control system for SWM in the region as a whole and in its separate parts.

- Absence of a common policy of St Petersburg and the Leningrad region in SWM does not allow solving effectively existing common problems and generates conflicts.

The common problems of St Petersburg and the Leningrad region in SWM are schematically submitted in Figure 4. 


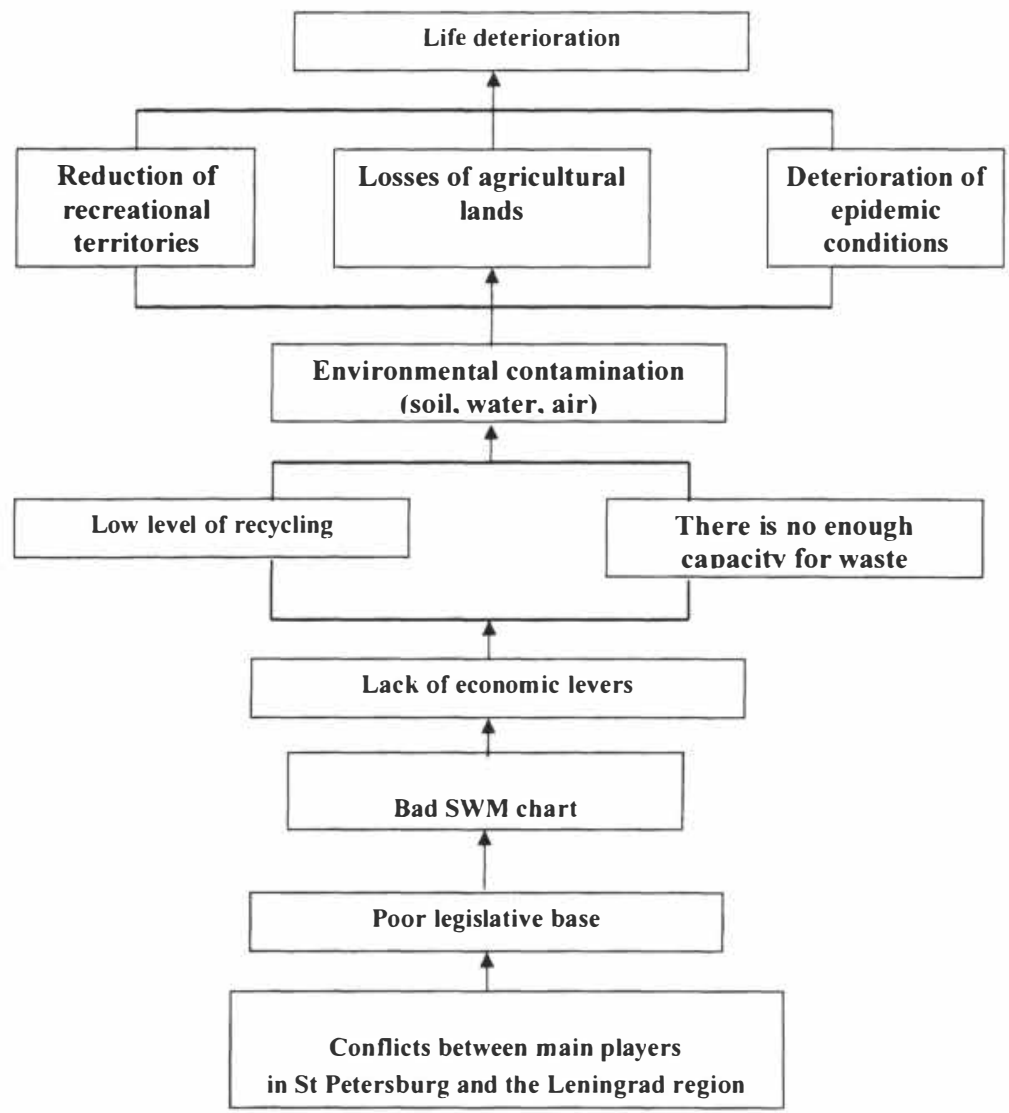

Figure 4. The basic problems of the region in SWM.

There are also the problems specific for the Leningrad region which solution is inconvenient without participation of the Administration of St Petersburg. Among these problems are following:

- Practically full absence in the Leningrad region of the enterprises for industrial processing of household, and also a significant part of industrial wastes;

- Absence of a system of waste disposal from the country and gardening settlements occupied by inhabitants of St Petersburg, but located in the Leningrad region.

The most important current problem is the development and providing of the uniform policy for SWM in St Petersburg and the Leningrad region.

Concrete directions of cooperation of the region and city during the nearest years can be the following questions:

- Optimization of regional and city tariffs for processing and landfilling of solid wastes; 
- Using of the capacities in St Petersburg on waste processing both existing, and planned to construction;

- Improvement and joint using of regional landfills for SW;

- Coordination of programs and plans of reconstruction of the infrastructure of for SWM in the Leningrad region and St Petersburg.

\section{POSSIBLE LANDFILLS FOR RECREANT LOADS}

St Petersburg enterprises for waste processing can accept up to 140 thousand ton of municipal solid waste that is about $40 \%$ from total waste in the Leningrad region. From the other side, St Petersburg needs new places for landfilling solid waste that could not be recycled or composted. For example, only in the year 200169 thousand ton of non-compostable waste have been produced at the waste processing enterprise No 2 including stones, broken glass, pieces of polymer films and etc.

One of the ways for improving SWM is the construction of new advanced landfills for municipal waste not subjected to industrial processing. But at the same time the construction of landfills is not the successful decision of a problem.

The basic requirements for landfills are following:

- Distance from a vein of building not less than 500 meters that is a sanitary - protective zone;

- Distance from airports not less than 10 kilometers;

- Distance from roads not less than 500 meters;

- Ground of the basis is clay or heavy loams;

- Level of subsoil waters no more than 2 meters;

- Height of storage not less than 10 meters;

- Square of the land area is selected from conditions of its operation not less than 15-20 years.

Estimated term of operation is 20 years. Annual specific norm of accumulation of waste with taking into account residential buildings and non-industrial objects per one year of designing is 0.4 cubic meters per one person per one year. The amount of the served population per one year of designing is 1,500 thousand persons (all gardening population). It is predicted that in 20 years total gardening population will be 1,900 thousand.

Capacity $E_{T}$ of the landfill for the estimated term is defined from the formula:

$E_{T}=\left(Y_{1}+Y_{2}\right)\left(P_{1}+P_{2}\right) T K_{2} / 4 K_{1}$

where: $Y_{1}$ и $Y_{2}$ - specific annual norms of accumulation of solid waste for the first and last years of operating; $P_{1}$ и $P_{2}$ - amount of the population served by the landfill for the first and last years of operating; $T$ estimated term of operation of the landfill; $K_{1}$ - the factor, which is taking into account densifying waste during the operation of the landfill for the whole term $T$; $K_{2}$ - the factor, which is taking into account the volume of external insulating layers of ground (intermediate and final).

Projected capacity of the landfill under the formula is: 
$E_{m}=(0,4+0,8) *(1500000+1900000) * 20 * 1,18 /(4 * 4)==5,664,000$ cubic meters.

Finally it gives 47 hectares of land for the landfill. Now it is zero.

\section{CONCLUSION}

Proposed measures need related organizational and financial support and can be realized only under conditions of the development of the appropriate investment infrastructure. 